\title{
A research on the influence of geological factors to gas discharge from No.8 un-mined solid coal seam of Baode Coal Mine
}

\author{
Yinghua $\mathrm{Lv}^{1,}$, , Shi Gang $\mathrm{An}^{1}$, Wen Xu Liang ${ }^{2,3}$, Dian Fu $\mathrm{Chen}^{1}$, and Wei $\mathrm{Fu}^{2,3}$ \\ ${ }^{1}$ CHN Energy Shendong Coal Group Co., Ltd., Shenmu 719315, China \\ ${ }^{2}$ Shenyang Research Institute, China Coal Technology and Engineering Group, Fushun 113122, \\ China \\ ${ }^{3}$ State Key Lab of Coal Mine Safety Technology, Fushun 113122, China
}

\begin{abstract}
Mining is gradually progressed toward the in-depth area of No. 8 solid coal seam in No.3 panel of Baode Coal Mine. In order to secure safe mining in this area, a systematic analysis is conducted on the geological factors that influence gas occurrence. Based on the basic data actually measured at site, grey relational analysis (GRA) is adopted for predictive analysis of influencing factors (depth, coal seam thickness, metamorphic grade, sand to mud ratio of roof, sand to mud ratio of floor, geological structure and washout), followed by establishment of a grey relational model. Then, the relation degree among factors is calculated, thus identifying the main controlling factors of gas occurrence. The research result suggests: the main geological factors that influence gas occurrence in No. 8 coal seam are geological structure and washout. A model equation is established for prediction of gas content using multiple regression method: $\mathrm{y}=3.2429+0.0047 \mathrm{X}_{1}+0.0079 \mathrm{X}_{2}-0.0180 \mathrm{X}_{3}+0.0016 \mathrm{X}_{4}-0.0215 \mathrm{X}_{5}+0.4641 \mathrm{X}_{6}$ $+0.2001 \mathrm{X}_{7}$. This equation demonstrates high degree of fitting.
\end{abstract}

\section{Introduction}

Baode coal mine is a high gassy mine with approved production capacity of $5 \mathrm{Mt} / \mathrm{a}$. Currently, the main mining area is No.8 coal seam. At present, since mining in Baode coal mine is progressing toward the in-depth area of No.3 panel, there has been increased gas content and gas discharge. Now, the maximum gas content within mining scope of has reached $8.99 \mathrm{~m}^{3} / \mathrm{t}$, causing increased risks of gas disaster. Therefore, it's necessary to strengthen the research on gas content in the in-depth area of coal seam, the essence of which is researching the geological factors that influence the gas occurrence in the coal seam.

\footnotetext{
*Corresponding author: 115214971@qq.com
} 


\section{Overview of No.8 coal seam}

\subsection{Basic information about No.8 coal mine}

No.8 coal seam is located above the $\mathrm{S}_{3}$ sandstone on the bottom of Shanxi Group $\left(\mathrm{P}_{1 \mathrm{~S}}\right)$. The coal seam thickness is between $1.85 \sim 9.01 \mathrm{~m}$ and $6.02 \mathrm{~m}$ on average. It's a thick to super-thick coal seam, with thick coal seam accounting for the major portion. The coal seam structure is simple $\sim$ complex, with $3 \sim 4$ dirt bands in general whose total thickness is between $0 \sim 3.84 \mathrm{~m}$ and $1.38 \mathrm{~m}$ on average. The gangue rocks mainly consist of mudstones, followed by carbon mudstones. The immediate roof of coal seam mostly consists ofsandy mudstones and mudstones and of kern stones locally. The bottom mainly consists of mudstones, followed by siltstones.

\subsection{Geological structure of No.8 coal seam}

The area is located at the north of Hedong coal field. The coal seam is of simple structure and demonstrates a gradualhomocline with development of wide and gradual undulation. As to theoverallattitude of stratum, the slope is $350^{\circ}$; the inclination is $260^{\circ}$ and the dip angle is between $3 \sim 9^{\circ}$ and $5^{\circ}$ in general. Except for small faults, no large faults, folds or collapse columnsare observed. According to measurement performed near the 7 actually exposed faults in No.3 panel, the average gas content is $6.35 \mathrm{~m}^{3} / \mathrm{t}$.

\subsection{Metamorphic grade of No.8 coal seam}

The No.8 coal seam mostly consists of long flame coal, together with minor gas coal. During coalification, with increased metamorphic grade, the gas is also increased accordingly. The average gas content is $5.87 \mathrm{~m}^{3} / \mathrm{t}$ in gas coal area and $5.28 \mathrm{~m}^{3} / \mathrm{t}$ in long coal area.

\subsection{The influencing factors of gas content in No.8 coal seam}

In order to facilitate analyzing the influencing factors of gas occurrence, a summary was made based on the previous test data at 165 places including belt conveyance lane 81310, crosscuts, crosscut 8 of No.1 and No.2 lanes in in-depth area of No.3 panel, the main conveyance land in the in-depth area of No.3 panel and auxiliary belt conveyance lane 81506 , thus obtaining actually measured parameters of influencing factors of gas occurrence (partial). 
Table 1. Actually measured parameters of influencing factors of gas occurrence (partial).

\begin{tabular}{|c|c|c|c|c|c|c|c|c|c|c|c|}
\hline$\underset{\dot{L}}{\dot{L}}$ & Location & E & 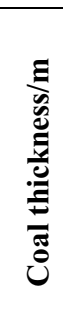 & 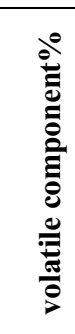 & 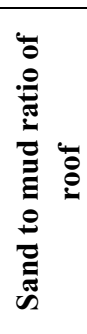 & 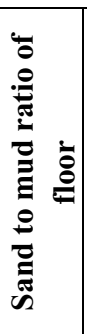 & 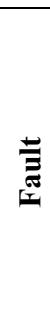 & 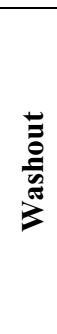 & 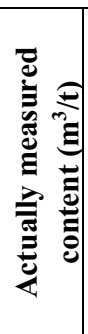 & 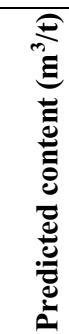 & \\
\hline 1 & $\begin{array}{c}\text { No.3 } \\
\text { crosscut of } \\
\text { belt } \\
\text { conveyance } \\
81310\end{array}$ & 338 & 8.1 & 34.2 & $2: 1$ & $9: 1$ & 0 & 1 & 4.38 & 4.29 & -2.10 \\
\hline 2 & $\begin{array}{c}\text { No.14 } \\
\text { crosscut of } \\
\text { belt } \\
\text { conveyance } \\
81310\end{array}$ & 440 & 7.2 & 34.2 & $2: 1$ & $9: 1$ & 1 & 1 & 6.51 & 6.23 & -4.49 \\
\hline 3 & $\begin{array}{c}\text { No.16 } \\
\text { crosscut of } \\
\text { belt } \\
\text { conveyance } \\
81310 \\
\end{array}$ & 450 & 6.9 & 32.2 & $2: 1$ & $9: 1$ & 0 & 1 & 5.02 & 4.85 & -3.51 \\
\hline 4 & $\begin{array}{c}\text { No.23 } \\
\text { crosscut of } \\
\text { belt } \\
\text { conveyance } \\
81310 \\
\end{array}$ & 430 & 7.6 & 27.7 & $2: 1$ & $9: 1$ & 0 & 0 & 5.95 & 5.64 & -5.50 \\
\hline 5 & $\begin{array}{c}\text { No.26 } \\
\text { crosscut of } \\
\text { belt } \\
\text { conveyance } \\
81310 \\
\end{array}$ & 418 & 8 & 31.4 & $2: 1$ & $9: 1$ & 0 & 1 & 5.2 & 5.18 & -0.39 \\
\hline 6 & $\begin{array}{c}\text { Opening of } \\
\text { belt } \\
\text { conveyance } \\
81311 \\
\end{array}$ & 321 & 8.1 & 39.3 & $1: 2$ & $2: 1$ & 0 & 1 & 4.52 & 4.27 & -5.85 \\
\hline 7 & $\begin{array}{c}\text { No.12 } \\
\text { crosscut of } \\
\text { belt } \\
\text { conveyance } \\
81311\end{array}$ & 482 & 7.1 & 32.5 & $1: 2$ & $2: 1$ & 1 & 0 & 6.54 & 6.41 & -2.03 \\
\hline 8 & $\begin{array}{c}\text { No.21 } \\
\text { crosscut of } \\
\text { belt } \\
\text { conveyance } \\
81311\end{array}$ & 478 & 7.4 & 30.5 & $1: 2$ & $2: 1$ & 0 & 0 & 5.86 & 4.96 & -18.15 \\
\hline
\end{tabular}




\begin{tabular}{|c|c|c|c|c|c|c|c|c|c|c|c|}
\hline 9 & $\begin{array}{c}\text { No. } 28 \\
\text { crosscut of } \\
\text { belt } \\
\text { conveyance } \\
81311\end{array}$ & 485 & 6.8 & 41.6 & $1: 2$ & $2: 1$ & 0 & 0 & 4.86 & 4.79 & -1.46 \\
\hline 10 & $\begin{array}{c}\text { No.31 } \\
\text { crosscut of } \\
\text { auxiliary } \\
\text { belt } \\
\text { conveyance } \\
81308\end{array}$ & 498 & 7.2 & 29.5 & $3: 1$ & $0.7: 1$ & 0 & 1 & 5.17 & 5.3 & 2.45 \\
\hline 11 & $\begin{array}{c}\text { Crosscut } 8 \\
\text { of No.1 } \\
\text { and No. } 2 \\
\text { lanes in } \\
\text { in-depth } \\
\text { area of } \\
\text { No.3 panel }\end{array}$ & 280 & 10.7 & 35.3 & $1: 5$ & $1: 1$ & 0 & 1 & 4.12 & 4.19 & 1.67 \\
\hline 12 & $\begin{array}{c}\text { Crosscut } \\
\text { 16of No.1 } \\
\text { and No.2 } \\
\text { lanes of } \\
81309\end{array}$ & 357 & 6.8 & 42.2 & $3: 1$ & $0.7: 1$ & 0 & 0 & 4.92 & 4.2 & -17.14 \\
\hline 13 & $\begin{array}{c}\text { Crosscut } \\
\text { 22of No.2 } \\
\text { lane of } \\
81309\end{array}$ & 393 & 5.8 & 37.1 & $1: 5$ & $1: 1$ & 0 & 1 & 4.38 & 4.65 & 5.81 \\
\hline 14 & $\begin{array}{c}\text { No. } 18 \\
\text { crosscut of } \\
\text { extended } \\
\text { lane in the } \\
\text { in-depth } \\
\text { area of } \\
\text { No.3 panel }\end{array}$ & 352 & 9.8 & 37.2 & $1: 5$ & $1: 1$ & 1 & 0 & 6.52 & 5.75 & -13.39 \\
\hline 15 & $\begin{array}{c}\text { No.9 } \\
\text { crosscut of } \\
\text { No.1 and } \\
\text { No.2 lanes } \\
\text { of extended } \\
\text { lane in the } \\
\text { in-depth } \\
\text { area of } \\
\text { No.3 panel }\end{array}$ & 302 & 10.4 & 32.2 & $1: 5$ & $1: 1$ & 0 & 0 & 4.26 & 4.61 & 8.16 \\
\hline
\end{tabular}




\begin{tabular}{|c|c|c|c|c|c|c|c|c|c|c|c|}
\hline 16 & $\begin{array}{c}\text { No.14 } \\
\text { crosscut of } \\
\text { No.2 lane } \\
\text { in the } \\
\text { in-depth } \\
\text { area of } \\
\text { No.3 panel }\end{array}$ & 312 & 10.3 & 38.4 & $1: 5$ & $1: 1$ & 0 & 1 & 5.71 & 4.74 & -16.94 \\
\hline 17 & $\begin{array}{c}\text { No. } 8 \\
\text { crosscut of } \\
\text { No.2 lane } \\
\text { in the } \\
\text { in-depth } \\
\text { area of } \\
\text { No.3 panel }\end{array}$ & 292 & 10.7 & 41.2 & $1: 5$ & $1: 1$ & 0 & 0 & 3.59 & 3.94 & 9.67 \\
\hline 18 & $\begin{array}{c}\text { No. } 12 \\
\text { crosscut of } \\
\text { the main } \\
\text { and } \\
\text { auxiliary } \\
\text { belt } \\
\text { conveyance } \\
\text { in the } \\
\text { in-depth } \\
\text { area of } \\
\text { No.3 panel }\end{array}$ & 569 & 9.6 & 37.5 & $1: 5$ & $1: 1$ & 0 & 0 & 5.49 & 5.76 & 4.94 \\
\hline 19 & $\begin{array}{c}120 \mathrm{~m} \\
\text { ahead the } \\
\text { No. } 17 \\
\text { crosscut of } \\
\text { extended } \\
\text { main and } \\
\text { auxiliary } \\
\text { belt } \\
\text { conveyance } \\
\text { in the } \\
\text { in-depth } \\
\text { area }\end{array}$ & 551 & 8.8 & 31.6 & $1: 5$ & $1: 1$ & 0 & 0 & 5.5 & 5.78 & 5.02 \\
\hline 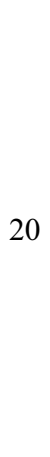 & $\begin{array}{c}120 \mathrm{~m} \\
\text { ahead the } \\
\text { No. } 22 \\
\text { crosscut of } \\
\text { the main } \\
\text { belt } \\
\text { conveyance } \\
\text { in the } \\
\text { in-depth } \\
\text { area of } \\
\text { No.3 panel }\end{array}$ & 493 & 6.6 & 35.2 & $1: 5$ & $1: 1$ & 0 & 0 & 5.59 & 5.16 & -7.74 \\
\hline
\end{tabular}




\begin{tabular}{|c|c|c|c|c|c|c|c|c|c|c|c|}
\hline 21 & $\begin{array}{c}\text { No.11 } \\
\text { crosscut of } \\
\text { No.1 and } \\
\text { No.2 lanes } \\
\text { in the } \\
\text { in-depth } \\
\text { area of } \\
\text { No.3 panel }\end{array}$ & 302 & 10.3 & 31.6 & $3.5: 1$ & $1.8: 1$ & 0 & 1 & 5.34 & 4.81 & -10.00 \\
\hline 22 & $\begin{array}{c}120 \mathrm{~m} \\
\text { ahead the } \\
\text { No. } 13 \\
\text { crosscut of } \\
\text { the } \\
\text { auxiliary } \\
\text { lane of } \\
81506\end{array}$ & 365 & 9.4 & 33.5 & $1: 2$ & $9: 1$ & 0 & 0 & 3.95 & 4.70 & 19.01 \\
\hline \multicolumn{2}{|c|}{ Relation degree } & 0.50 & 0.48 & 0.55 & 0.58 & 0.19 & 0.74 & 0.66 & - & - & - \\
\hline \multicolumn{2}{|c|}{$\begin{array}{l}\text { Ranking of } \\
\text { relation degree }\end{array}$} & 5 & 6 & 4 & 3 & 7 & 1 & 2 & - & - & - \\
\hline
\end{tabular}

\subsection{Linear analysis of influencing factors of gas occurrence}

The coal seam depth is a main factor that influences the gas content. A lot of practice proves that the deeper the coal seam, the greater the gas pressure and absorbed gas, resulting in increased gas content. There is mutual influence among the content, depth, coal seam thickness, metamorphic grade and geological structure, with great difference at different locations. Upon summary and analysis of data, the relation between partial parameters and gas content is shown in Figure 1 and Figure 2.

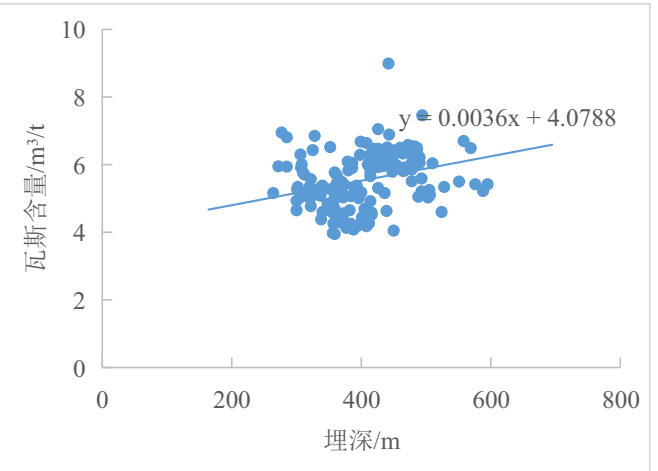

Fig. 1. Relation between depth and gas content. 


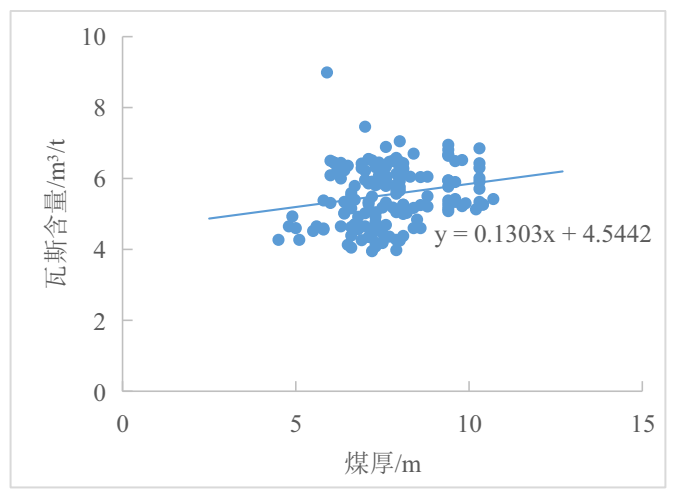

Fig. 2. Relation between coal seam thickness and gas content.

\section{Principle of grey relational analysis}

Relation degree refers to the degree of relation between changes of factors between two systems with time or different objects ${ }^{[1]}$. In system development, if the change trend of two factors is consistent, or namely they demonstrate highly synchronous change, the relation degree is high; otherwise, the relation degree is low. Therefore, grey relational analysis refers to a method of measuring the relation degree among factors based on the similarity or diversity (namely, grey relation degree) of development trend of factors.

\subsection{Basic steps of grey relational analysis ${ }^{[3-5]}$}

(1) Determine the reference sequence which reflects the characteristics of system behavior and the comparison sequence which influences system behavior. The data sequence which reflects the characteristics of system behavior is referred to as reference sequence; the data sequence which influences the factors composition of system behavior is referred to as comparison sequence.

(2) Non-dimensionalize reference sequence and comparison sequence

Since the physical significance of factors is different in a system, the dimension of data also varies, resulting in inconvenience in comparison or failure to obtain correct conclusion in comparison. Therefore, the data is generally non-dimensionalized in grey relational analysis.

(3) Solve the grey relation coefficient $\xi\left(\mathrm{X}_{\mathrm{i}}\right)$ between reference sequence and comparison sequence

The relation degree is, in essence, the degree of difference between the geometrical shapes of curves. Therefore, the degree of difference of curves may serve as the gauge for measuring relation degree. For a reference sequence $\mathrm{X} 0$ which has several comparison sequences $X_{1}, X_{2}, \ldots, X_{n}$, the relation coefficient $\xi\left(X_{i}\right)$ between comparison sequence and reference sequence at each moment (namely, each point in the curves) may be calculated with the following formula: where, pis distinguishing coefficientwhose value is between $0 \sim 1$ and 0.5 in general.

$\Delta$--Minimal difference of the second order, denoted as $\Delta_{\min }$. In case of maximal difference of the second order, it's denoted as $\Delta_{\max }$. The absolute difference value between each point on the curve $\mathrm{X}_{\mathrm{i}}$ of comparison sequence and that on the curve $\mathrm{X}_{0}$ of reference sequence is denoted as $\Delta_{\mathrm{oi}}(\mathrm{k})$.

Therefore, the relation coefficient $\xi(\mathrm{Xi})$ may be simplified into the following formula: 


$$
\xi_{0 i}=\frac{\Delta(\min )+\rho \Delta(\max )}{\Delta_{0 i}(k)+\rho \Delta(\max )}
$$

(4) Solve the relation degree $r_{i}$

Since relation coefficient refers to the relation degree between comparison sequence and reference sequence at each moment (namely, each point on the curves), there are more than one values. However, dispersive information is not convenient for overall comparison. Therefore, it's necessary to centralize the relation coefficient at each moment (namely, each point on the curves) into one value, that is, to solve the mean value to indicate the relation degree between comparison sequence and reference sequence. The formula of relation degree ri is as follows:

$$
r_{i}=\frac{1}{N} \sum_{k=1}^{N} \xi_{i}(k)
$$

$\mathrm{r}_{\mathrm{i}}-$-the grey relation degree between comparison sequencex $\mathrm{x}_{\mathrm{a}}$ and reference sequence $\mathrm{x}_{0}$. It's also referred to as sequence relation degree, average relation degree, or linear relation degree. The closer the $\mathrm{r}_{\mathrm{i}}$ value to 1 , the greater the relation.

(5) Ranking of relation degree

The relation degree among factors is mainly described with the significance and ranking, not merely by the significance. The relation degree between $\mathrm{m}$ sub-sequences and the same parent sequence is ranked into a relational order as per the significance and denoted as $\{\mathrm{x}\}$, reflecting the "priority" of sub-sequences concerning their relation with parent sequence. $\operatorname{Ifr}_{0}>\mathrm{r}_{0 j}$, then the priority of $\left\{\mathrm{x}_{\mathrm{i}}\right\}$ is higher than that of $\left\{\mathrm{x}_{\mathrm{j}}\right\}$ for the same parent sequence, denoted as $\left\{\mathrm{x}_{\mathrm{i}}\right\}>\left\{\mathrm{x}_{\mathrm{j}}\right\} ; \mathrm{r}_{0 \mathrm{i}}$ is the characteristic value of No.i sub-sequence against the parent sequence.

Grey relational analysis is the comparison of points on the same line which being the factor values of research object and its influencing factors with the curve drawn from factor values of object to be identified and its influencing factors. The proximityis compared and quantized, thus calculating the relation degree of proximity of influencing factors between researched object and the object to be identified. The degree of influence of object to be identified to the researched object is judged through comparison of significance of relation degree.

\subsection{Grey relational analysis of influencing factors of gas content}

The grey relational comprehensive evaluation is adopted for revealing the strength of relation between gas content and its influencing factors, the characteristics of coal seam and geological features in the area. The depth, thickness and structure of coal seam and the sand to mud ratio of roof and floor are taken as independent variables which constitute as a comparison sequence (the qualitative data is converted into quantitative data. According to the theory of quantification, it is often denoted with binary state variable. Namely, "1" and " 0 " are used to indicate "existence" or "non-existence" of certain properties), while gas content is taken as a dependent variablethat serves as the reference sequence.

A variable sequence array is established based on the original data. Then, the original data array is non-dimensionalized through equalization, thus obtaining difference sequence array. Where the distinguishing coefficient $\rho=0.5$, the relation coefficient of each factor is calculated, thus obtaining relation coefficient array. Finally, the relation degree between 
gas content and its influencing factors is solved, as shown in Table 1. The top-down ranking of main influencing factors of gas content is as follows: faults, sand to mud ratio of roof, coal seam depth, thickness of coal seam, content of volatile component, sand to mud ratio of floor, washout.

\subsection{Prediction of gas content}

Upon foregoing grey relational analysis, the main influencing factors of gas occurrence are identified. On this basis, a gas content prediction model may be established through multiple regression analysis. With borehole gas content as a dependent variable (y) and influencing factors as independent variables $\left(\mathrm{x}_{1}, \mathrm{x}_{2}, \ldots, \mathrm{x}_{6}(1,2,3, \ldots\right.$ refers to the ranking of relation degree of factors)), the actually measured or statistical data are input into computer. Then, the regression analysis program in Excel is used to obtain gas content regression prediction model and statistical inspection index ${ }^{[4-6]}$ :

Based on foregoing research, the total seven influencing factors of depth, coal seam thickness, metamorphic grade, sand to mud ratio of roof, sand to mud ratio of floor, geological structure and washout are denoted as $\mathrm{X}_{1}, \mathrm{X}_{2}, \mathrm{X}_{3}, \mathrm{X}_{4}, \mathrm{X}_{5}, \mathrm{X}_{6}$ and $\mathrm{X}_{7}$ respectively. With gas content as a dependent variable (y), their actually measured data is input into computer. Then, the regression analysis program in Excel is used to obtain gas content regression prediction model and statistical inspection index (See Table 2):

$$
\mathrm{y}=3.2429+0.0047 \mathrm{X}_{1}+0.0079 \mathrm{X}_{2}-0.0180 \mathrm{X}_{3}+0.0016 \mathrm{X}_{4}-0.0215 \mathrm{X}_{5}+0.4641 \mathrm{X}_{6}+0.2001 \mathrm{X}_{7} \text { 。 }
$$

Table 2. Indexes in the grey analysis theory.

\begin{tabular}{|c|c|c|c|c|c|c|c|c|}
\hline 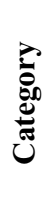 & نُ & 总 & $\stackrel{\bar{\pi}}{\vec{\omega}}$ & İ & 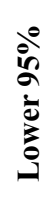 & 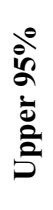 & 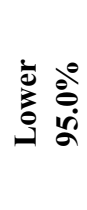 & 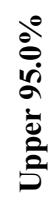 \\
\hline 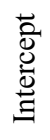 & 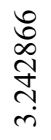 & $\begin{array}{l}\frac{+}{\hat{a}} \\
\text { ळे } \\
\text { m. }\end{array}$ & 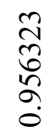 & $\begin{array}{l}\stackrel{2}{R} \\
\hat{N} \\
\text { ñ } \\
0\end{array}$ & $\frac{\stackrel{\Re}{\sim}}{\stackrel{Ð}{+}}$ & $\begin{array}{l}\stackrel{0}{\ddots} \\
\bar{\sigma} \\
\stackrel{0}{0}\end{array}$ & 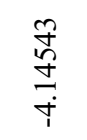 & $\begin{array}{l}0 \\
\overline{=} \\
\underline{3} \\
0 \\
0\end{array}$ \\
\hline 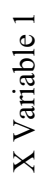 & $\begin{array}{l}\stackrel{\overbrace{}}{N} \\
\stackrel{+}{8} \\
\stackrel{8}{0}\end{array}$ & 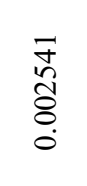 & $\begin{array}{l}\text { D } \\
\dot{+} \\
\infty \\
\infty \\
\infty \\
-1\end{array}$ & $\begin{array}{l}\overrightarrow{0} \\
\infty \\
\infty \\
0 \\
0 \\
0\end{array}$ & $\begin{array}{l}\vec{\infty} \\
8 \\
8 \\
0 \\
0\end{array}$ & 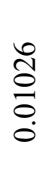 & $\begin{array}{l}\vec{\infty} \\
8 \\
8 \\
\dot{0} \\
\dot{0}\end{array}$ & 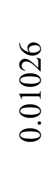 \\
\hline 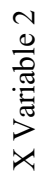 & 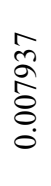 & 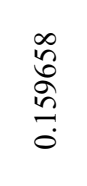 & $\begin{array}{l}0 \\
\hat{\sigma} \\
\text { 守 } \\
0 \\
0\end{array}$ & $\begin{array}{l}\hat{\sigma} \\
\bar{\sigma} \\
0 \\
0 \\
0\end{array}$ & $\begin{array}{l}\text { } \\
\text { ले } \\
\text { ?े } \\
\hat{1}\end{array}$ & $\begin{array}{l}\text { o } \\
0 \\
n \\
n \\
n \\
0\end{array}$ & $\begin{array}{l}n \\
\text { ळे } \\
\stackrel{n}{0} \\
1\end{array}$ & $\begin{array}{l}\text { ô } \\
\infty \\
n \\
n \\
n \\
0\end{array}$ \\
\hline
\end{tabular}




\begin{tabular}{|c|c|c|c|c|c|c|c|c|}
\hline 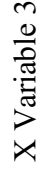 & $\begin{array}{l}\text { Oे } \\
\stackrel{\infty}{0} \\
0 \\
0 \\
\end{array}$ & $\begin{array}{l}\stackrel{N}{\infty} \\
\stackrel{\infty}{0} \\
\stackrel{0}{0}\end{array}$ & $\begin{array}{l}\text { J } \\
\text { ก } \\
0 \\
\text { in }\end{array}$ & $\begin{array}{l}\text { ते } \\
\text { †े } \\
\stackrel{+}{0}\end{array}$ & 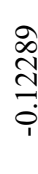 & $\begin{array}{l}\bar{n} \\
\infty \\
0 \\
\infty \\
0 \\
0\end{array}$ & $\begin{array}{l}\text { oे } \\
\text { ปे } \\
\stackrel{1}{0}\end{array}$ & $\begin{array}{l}\bar{n} \\
\infty \\
\infty \\
\infty \\
0 \\
0\end{array}$ \\
\hline 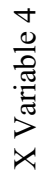 & $\begin{array}{l}\infty \\
\text { Ð } \\
\stackrel{0}{8} \\
0 \\
0\end{array}$ & 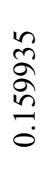 & $\begin{array}{l}\stackrel{0}{0} \\
\text { o } \\
0 \\
0 \\
0\end{array}$ & 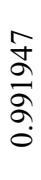 & $\begin{array}{l}0 \\
\infty \\
0 \\
+ \\
? \\
?\end{array}$ & $\begin{array}{l}0 \\
0 \\
0 \\
n \\
? \\
0\end{array}$ & 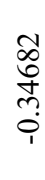 & $\begin{array}{l}\stackrel{0}{0} \\
\overrightarrow{0} \\
\stackrel{n}{0} \\
?\end{array}$ \\
\hline $\begin{array}{l}n \\
\frac{0}{\pi} \\
\frac{\pi}{\tilde{J}} \\
\frac{\pi}{\pi} \\
x\end{array}$ & 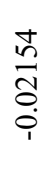 & 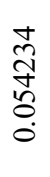 & $\begin{array}{l}\stackrel{2}{\hat{\sigma}} \\
\text { ஸे } \\
\stackrel{0}{1}\end{array}$ & 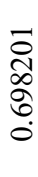 & 命 & 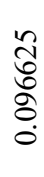 & 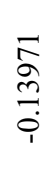 & 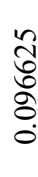 \\
\hline 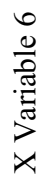 & \begin{tabular}{l} 
\\
\multirow{J}{*}{} \\
+ \\
$\dot{0}$
\end{tabular} & 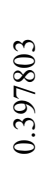 & $\begin{array}{l}\text { :े } \\
\text { : } \\
=\end{array}$ & 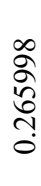 & 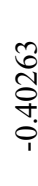 & 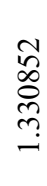 & 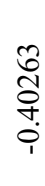 & 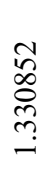 \\
\hline 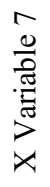 & 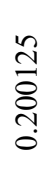 & 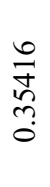 & $\begin{array}{l}\infty \\
\stackrel{0}{0} \\
\stackrel{0}{b} \\
? \\
0\end{array}$ & 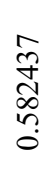 & $\frac{n}{n}$ & 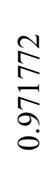 & $\frac{n}{n}$ & $\frac{N}{\stackrel{N}{ล}}$ \\
\hline
\end{tabular}

The multiple correlation coefficient $\mathrm{R}^{2}=0.92$ and the test statisticsF $=43.83>\mathrm{F} 0.01(5$, 12) $=10.47$, suggesting that the foregoing regression formula demonstrates high significance and the degree of fitting. The gas content predicted as per the prediction formula is shown is Table 1. Upon the comparison of predicted content and the actually measured content, the error was basically below $10 \%$. At some individual sites, the error was greater due to geological abnormal inference, man-made mining disturbance and testing factors of experimental data, etc.

\section{Conclusion and suggestions}

(1) The strength of geological factors that influence the gas occurrence (content) in No.8 coal seam of Baode coal mine were evaluated through grey relational comprehensive evaluation. The result suggests that the top-down ranking of main influencing factors of gas content is as follows: faults, washout, coal seam thickness, sand to mud ratio of roof, coal seam depth, content of volatile component, sand to mud ratio of floor.

(2) A model equation is established for prediction of gas content using multiple regression method:

$$
\mathrm{y}=3.2429+0.0047 \mathrm{X}_{1}+0.0079 \mathrm{X}_{2}-0.0180 \mathrm{X}_{3}+0.0016 \mathrm{X}_{4}-0.0215 \mathrm{X}_{5}+0.4641 \mathrm{X}_{6}+0.2001 \mathrm{X}_{7}
$$

The equation demonstrated high degree of fitting. With this equation, the gas occurrence in un-mined area may be predicted, thus enabling adoption of targeted measures for prevention and treatment of gas discharge. 


\section{References}

1. Zhou Wenhao, Zeng Bo, Statistics and Decision 15, 29-34 (2020)

2. Deng Hui, World Nonferrous Metals 08, 288-290 (2020)

3. Xu Gang, Wang Yunlong, Zhang Tianjun, Pan Hongyu, Han Yawei, Analysis of Main Controlling Factors of Gas Content at ParagenicOre of Coal, Oil and Gas and the Gas Treatment on the Working Surface

4. Xu Gang, Wang Lei, Wang Haitao, Wang Kai, Feng Yuanzhao, Coal Technology 38(11), 82-85 (2019)

5. Shen Lan, Mining Research and Development 39(10), 160 (2019)

6. WANG Lu'ou, XIE Xionggang, ZHAO Weixiang, Mining Technology 19(04), 60-64 (2019) 